\title{
PENAMBAHAN LEMPUNG UNTUK MENINGKATKAN NILAI CBR TANAH PASIR PADANG
}

\author{
Abdul Hakam ${ }^{1}$
}

\begin{abstract}
ABSTRAK
Pengujian yang dilakukan dalam penelitian ini adalah berupa pengujian sifat-sifat fisik dari tanah pasir asli dan tanah lempung, pemadatan dan pengujian CBR tanah asli dan campuran. Tanah pasir yang digunakan dalam penelitian ini diambil dari daerah pesisir pantai Kota Padang. Pengujian CBR untuk tanah campuran (tanah pasir pantai dan penambahan 20\% tanah lempung) pada kadar air optimum yang diperoleh dari pemadatan tanah campuran dan pada variasi kadar air lempung $20 \%, 40 \%, 60 \%, 80 \%, 100 \%$, dan 130\%. Hasil pengujian ini dapat memberikan indikasi bahwa metode stabilisasi tanah yang dilakukan, dapat memperbaiki sifat-sifat fisik dan daya dukung tanah pasir pantai. Dengan penambahan tanah lempung pada tanah pasir dapat meningkatkan nilai CBR dari tanah pasir itu sendiri.
\end{abstract}

Kata Kunci : Tanah pasir, tanah lempung, CBR.

\section{PENDAHULUAN}

Tanah mempunyai peranan yang sangat penting sebagai media pondasi untuk meyebarkan beban bangunan kedalamnya. Selain sebagai penerima saluran beban akhir, tanah juga digunakan sebagai bahan konstruksi dari bangunan itu sendiri, seperti tanggul dan jalan raya. Kondisi tanah di setiap tempat sangatlah berbeda karena tanah secara alamiah merupakan material yang rumit dan sangat bervariasi. Apabila suatu tanah yang terdapat di lapangan bersifat sangat lepas atau sangat lunak sehingga tidak sesuai untuk suatu pembangunan, maka tanah tersebut sebaiknya distabilisasi.

Tanah sepanjang pesisir Pantai Padang merupakan tanah jenis pasir dengan gradasi seragam. Sifat ini merupakan sifat yang sangat kurang baik sehingga perlu adanya stabilisasi pada tanah ini. Sifat tanah yang kurang baik ini sebenarnya dapat diperbaiki dengan melakukan penambahan jenis tanah lain yang berbeda sedemikian rupa, sehingga campuran tersebut merupakan suatu kesatuan yang menimbulkan peningkatan terhadap nilai mekaniknya.

Penelitian tentang penstabilan tanah telah banyak dilakukan baik dalam dan luar negeri (Ingles, O.G. and Metcalf, J.B., 1972 dan Jingga, Rama, 2008). Sebelum melakukan stabilisasi, semua material tanah harus diuji sifat fisik dan teknisnya dengan mengacu kepada pengujian yang telah distandarkan (lihat: Bowles, Joseph E, ,1984 dan ASTM Standards, 1989).

Distribusi ukuran butir, bentuk butiran, berat jenis dan mineral lempung yang terdapat dalam tanah merupakan hal fisik yang memberikan pengaruh terhadap sifat fisik lainnya, seperti berat volume maksimum dan kadar air optimum saat dipadatkan. Gambar 1 menunjukkan kurva-kurva pemadatan yang diperoleh dari beberapa macam tanah, yang diuji menurut prosedur pemadatan ASTM D-689. Bentuk kurva yang mendekati lonceng (bel), umumnya diperoleh pada tanah-tanah berlempung.

\footnotetext{
${ }^{1}$ Staf Pengajar Jurusan Teknik Sipil Fakultas Teknik Universitas Andalas, e-mail: ahakam@fft.unand.ac.id
} 


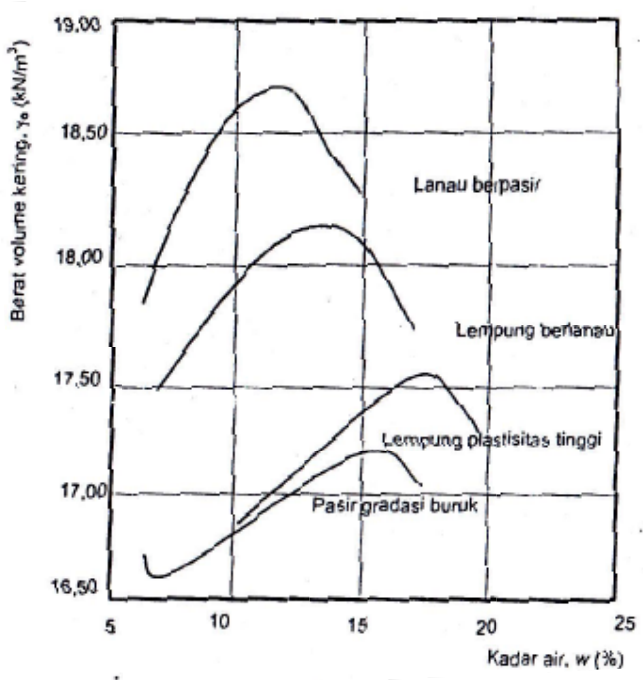

Gambar 1. Kurva Perbandingan Kadar Air terhadap Berat Volume Kering dari Hasil Pemadatan

Secara umum untuk tanah pasir pada proses pemadatan, berat volume kering tanah $\left(\gamma_{d}\right)$ akan cenderung berkurang saat kadar airnya bertambah. Pengurangan $\gamma_{d}$ ini adalah akibat dari pengaruh hilangnya tekanan kapiler saat kadar air bertambah. Pada kadar air rendah, tekanan kapiler dalam tanah yang berada di dalam rongga pori menghalangi kecenderungan partikel tanah untuk bergerak, sehingga butiran cenderung merapat (padat).

Lee dan Suedkamp (1972) telah memberikan kurva-kurva pemadatan untuk 35 jenis tanah. Hasilnya terdapat beberapa perbedaan bentuk kurva pemadatan. (Gambar 2). Kurva tipe A adalah kurva yang mempunyai satu puncak. Tipe B mempunyai bentuk seperti huruf $S$ pada arah mendatar. Tipe $C$ mempunyai dua puncak. Kurva tipe B dan $\mathrm{C}$ adalah kurva pemadatan yang dapat diperoleh pada tanah yang mempunyai batas cair $(L L)$ kurang dari 30 . Kurva tipe $\mathrm{D}$ adalah kurva yang tidak mempunyai puncak. Kurva C dan D dapat terjadi pada pemadatan tanah-tanah dengan batas cair $(L L)$ lebih besar 70 .

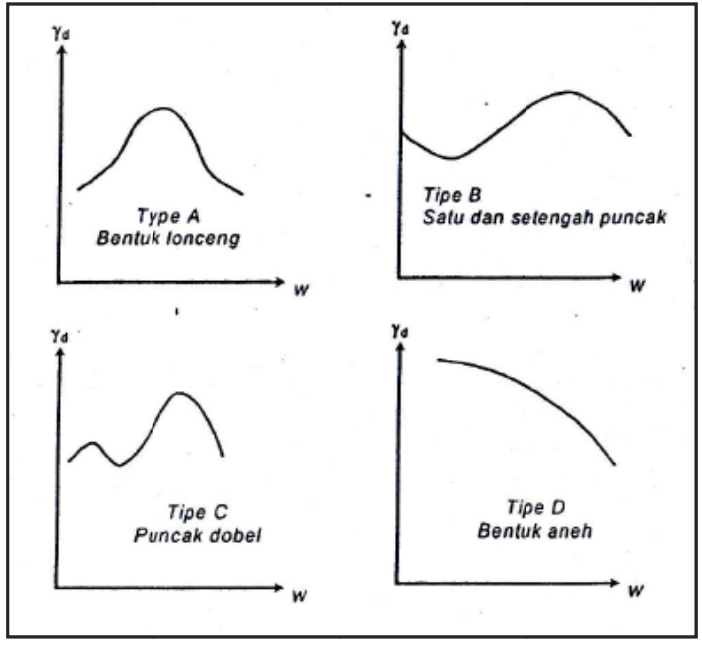

Gambar 2. Bentuk-Bentuk Kurva Pemadatan (Lee dan Suedkamp, 1972 dalam Das, 1995)

Energi pemadatan per volume satuan $(E)$ dapat dinyatakan oleh persamaan :

$$
E=\frac{N_{b} N_{l} W H}{V}
$$

dengan,

$N_{b}=$ jumlah pukulan per lapisan

$N_{l}=$ jumlah lapisan

$W=$ berat pemukul

$H=$ tinggi jatuh pemukul

$V=$ volumen mould 


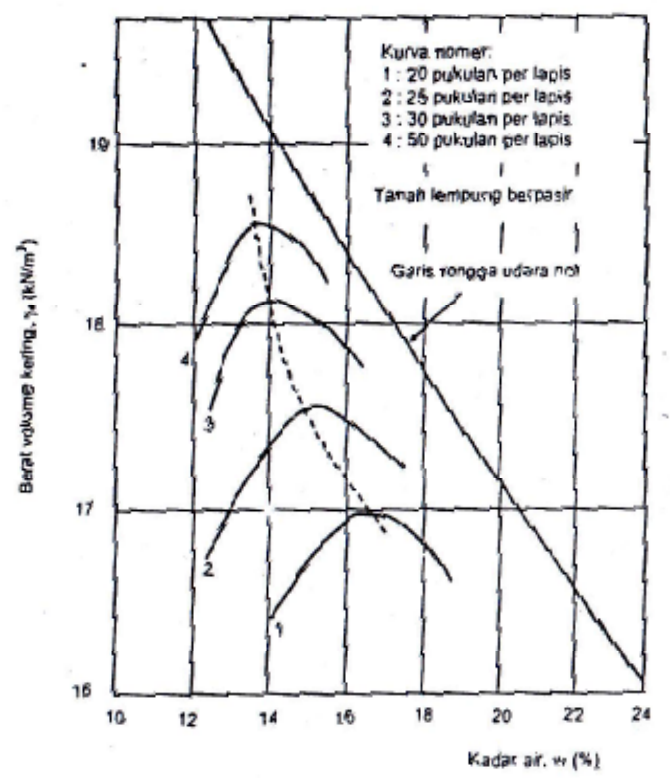

Gambar 3. Pengaruh Energi Pemadatan pada Hasil Pemadatan Lempung Berpasir (Das, 1995)

Jika usaha pemadatan per satuan $(E)$ berubah, maka bentuk kurva hubungan kadar air terhadap berat volume kering juga berubah. Berdasarkan keadaan tersebut maka dapat ditarik kesimpulan secara umum bahwa :

1. Jika energi pemadatan ditambah, berat volume kering tanah juga bertambah.

2. Jika energi pemadatan ditambah, kadar air optimum berkurang.

Kedua hal tersebut berlaku untuk hampir semua jenis tanah. Namun harus diperhatikan bahwa derajat kepadatan tidak secara langsung proporsional dengan energi pemadatan.

\section{PROPERTIES TANAH PASIR}

Pengujian sifat-sifat fisik tanah pasir yang dilakukan di Laboratorium Mekanika Tanah ditampilkan pada Tabel 1 berikut :

\section{Tabel 1. Hasil Pengujian Sifat-Sifat Fisik Tanah}

\begin{tabular}{|l|l|c|}
\hline \multicolumn{1}{|c|}{ Jenis Pengujian } & \multicolumn{1}{c|}{ Parameter } & Nilai \\
\hline Berat Jenis & Gs tanah pasir & 2,664 \\
\hline Berat Isi Basah (Berat Volume Basah) (Tanah Pasir) & $\gamma$ (gram/cm $\left.{ }^{3}\right)$ & 1,609 \\
\hline Kadar Air & $w$ pasir & $26,611 \%$ \\
& $w$ lempung & $68,176 \%$ \\
\hline Atterberg Limit (Tanah Lempung) & Liquid Limit (LL) & $125,0 \%$ \\
& Plastic Limit (PL) & $44,53 \%$ \\
& Plastisitas Indeks (PI) & $80,47 \%$ \\
\hline Analisa Saringan & \% lolos saringan \# 200 dari & $2,36 \%$ \\
(Tanah Pasir) & keseluruhan sampel. & \\
& Analisa ukuran butiran : & \\
& Gravel & $0,00 \%$ \\
& Pasir & $97,64 \%$ \\
& Lanau & $2,36 \%$ \\
\hline
\end{tabular}


Selanjutnya pengujian Analisa Saringan ditampilkan pada grafik dalam Gambar $\mathbf{4}$ di bawah ini :

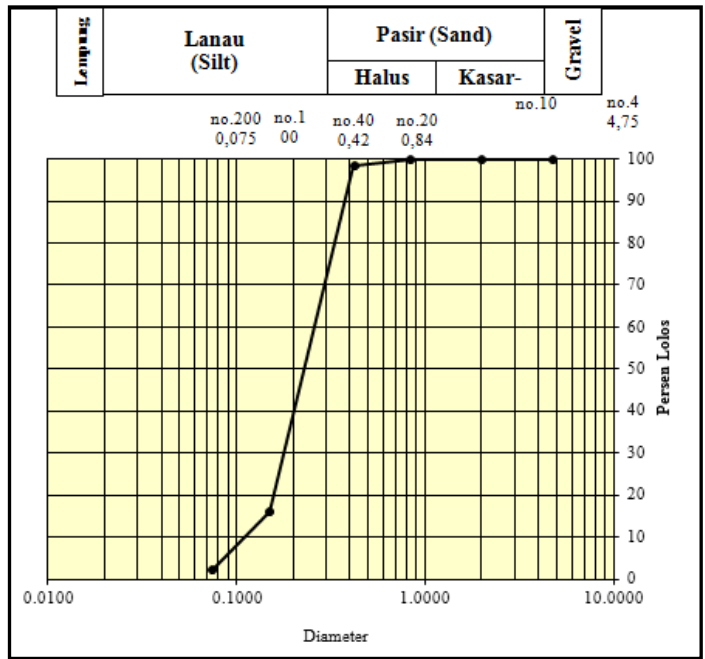

Gambar 4. Grafik Analisa Saringan

\section{HASIL PEMADATAN}

Pengerjaan pemadatan tanah telah dilakukan (Terimakasih kepada Imelia Yunita), di Laboratorium Mekanika Tanah Universitas Andalas. Pengujian pemadatan tanah campuran pasir dan lempung ini menggunakan variasi persentase tanah lempung sebesar $2 \%$, 5\%, 10\%, 20\%, dan 50\%. Hasil dari pengujian pemadatan ini ditampilkan pada Tabel 2, Gambar 5 dan Gambar 6.

\section{Tabel 2. Hasil Pengujian Pemadatan Tanah Campuran}

\begin{tabular}{|c|c|}
\hline Jenis Sampel & $\gamma_{\boldsymbol{d}}\left(\mathbf{t} / \mathbf{m}^{\mathbf{3}}\right)$ \\
\hline Pasir +2\% Lempung & 1,57 \\
\hline Pasir +5\% Lempung & 1,58 \\
\hline Pasir+10\% Lempung & 1,64 \\
\hline Pasir+20\% Lempung & 1,74 \\
\hline Pasir+50\% Lempung & 1,61 \\
\hline
\end{tabular}

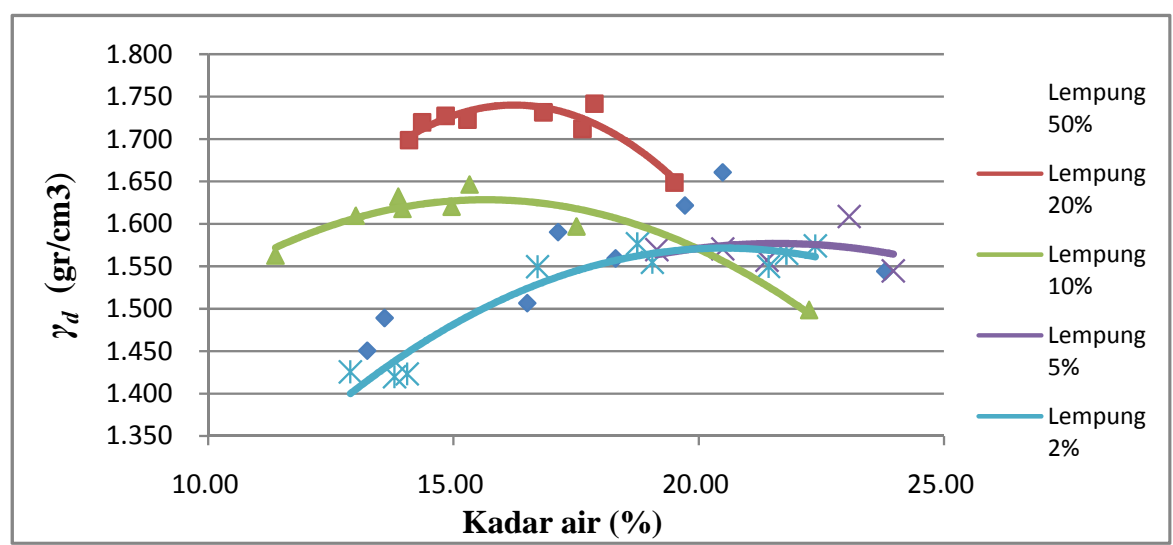

Gambar 5. Grafik Pemadatan Tanah Campuran

\section{I J URNAL REKAYASA SIPIL}




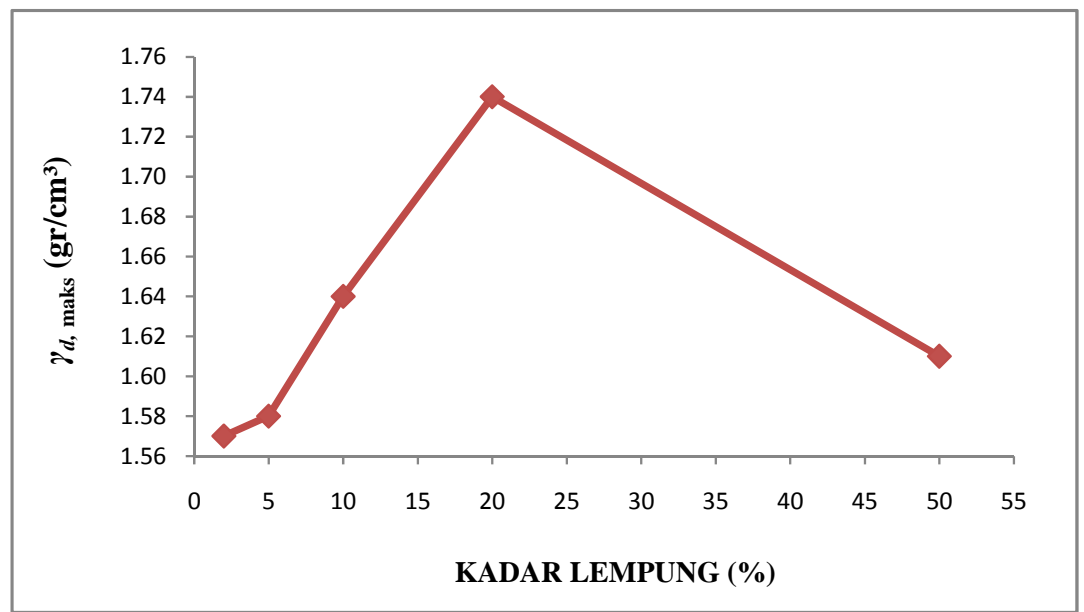

Gambar 6. Grafik Hubungan Kadar Lempung terhadap $\gamma_{d}$

Menurut hasil pengujian pemadatan di atas, setiap variasi campuran tanah pasir-lempung diperoleh nilai optimum dari kerapatan kering maksimum masing-masing. Namun, nilai kepadatan kering terbesar terjadi pada komposisi campuran pasir $+20 \%$ lempung. Berat kering maksimum $\left(\gamma_{d}\right)$ campuran pasir $+20 \%$ lempung adalah sebesar $1,74 \mathrm{t} / \mathrm{m}^{3}$ dengan kadar air optimum ( $w_{\text {opt }}$, campuran $)$ sebesar $16,5 \%$.

Dengan serangkaian pengujian CBR khusus untuk tanah pasir dengan penambanahan lemung 20\%, selanjutnya dapat ditarik hubungan antara variasi kadar air lempung terhadap nilai CBR dapat dilihat pada grafik berikut :

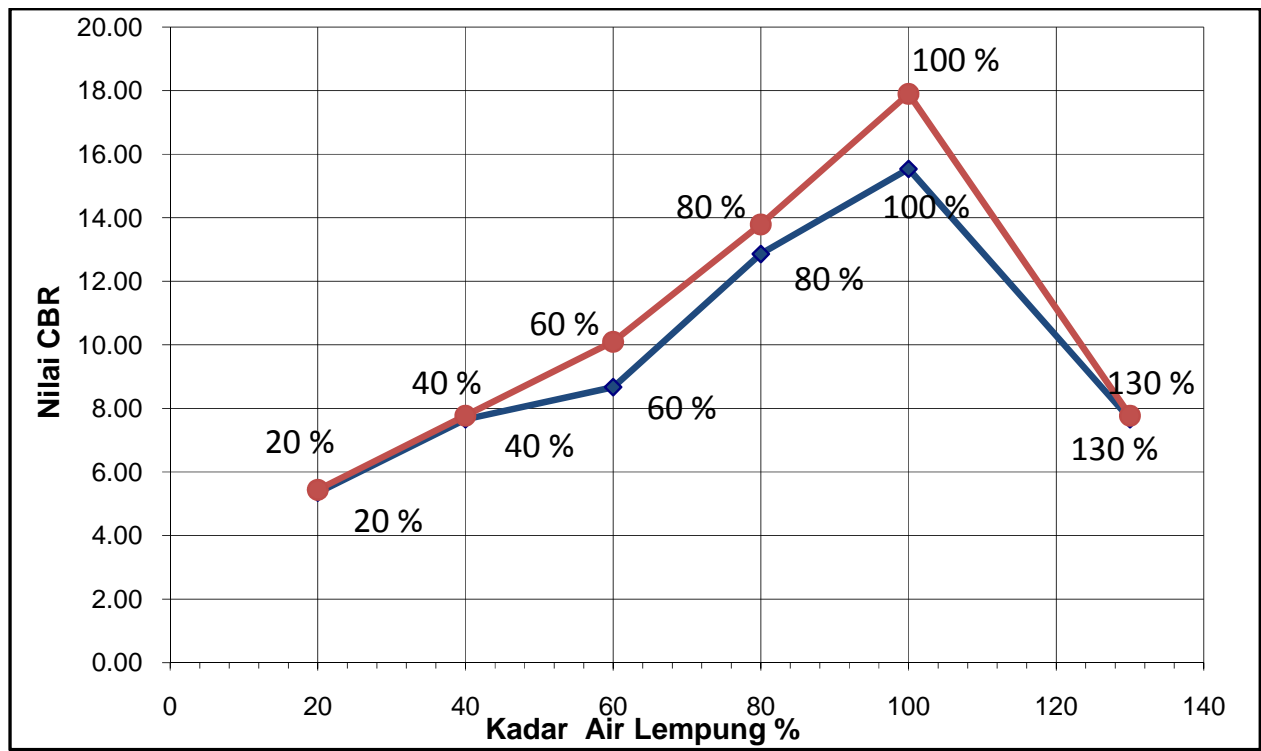

Gambar 7. Kurva Hasil Percobaan CBR Pada Tanah Campuran (Tanah Pasir $+20 \%$ Lempung)

Keterangan :

Penetrasi 0.2 ”

Penetrasi 0.1" 
Dari hasil pengujian CBR pada tanah campuran dengan kadar air pada tanah lempung yang berbeda di peroleh nilai CBR tertinggi pada kadar air 100\% dengan nilai 15,54\% pada penetrasi 0,1” dan $17,90 \%$ pada penetrasi 0,2 '.

Grafik di atas juga menunjukkan bahwa semakin besar prosentase kadar air lempung yang diberikan pada tanah campuran maka nilai CBR tanah akan semakin meningkat. Namun saat dilakukan penambahan kadar air lempung sebesar 130\% nilai CBR tanah berkurang. Hal ini menandakan pada kadar air 100\% tanah telah mencapai komposisi yang tepat antara tanah lempung dan air yang berfungsi sebagai pengikat antar butiran pasir untuk mendapatkan nilai CBR tertinggi. Lewat dari kadar air tersebut kondisi tanah mulai cair karena terlalu banyak mengandung air sehingga kondisi tanah menjadi lembek. Kondisi tanah yang demikian nilai daya dukungnya akan rendah. Dalam percobaan ini dapat dilihat dari nilai CBR yang diperoleh turun.

Dengan membandingkan hasil pengujian CBR antara kadar air optimum dengan variasi kadar air pada lempung, dapat disimpulkan nilai CBR pada variasi kadar air lempung jauh lebih kecil dibandingkan dengan campuran sampel dengan menggunakan kadar air optimum.

\section{KESIMPULAN}

Berdasarkan hasil rangkaian pengujian pemadatan dan CBR dari tanah pasir pantai dengan penambahan lempung, dapat ditarik kesimpulan bahwa tanah pasir Pantai Padang yang tergolong dalam tanah yang memiliki daya dukung (CBR) yang jelek dapat distabilisasi dengan menggunakan tanah lempung. Penambahan tanah lemung $20 \%$ pada tanah pasir pantai merupakan nilai terbaik untuk dapat meningkatkan nilai CBR dari campuran tersebut dibandingkan dengan porsi penambahan lainnya.

\section{DAFTAR PUSTAKA}

Annual Books of ASTM Standards, (1989), American Society for Testing material, Philadelphia.

Bowles, Joseph E, (1984), Sifat-Sifat Fisik dan Geoteknis Tanah (Mekanika Tanah), Edisi kedua, Erlangga, Jakarta.

Das, Braja M, (translated by Mochtar.N.E and Mochtar I.B.), (1995), "Mekanika Tanah (PrinsipPrinsip Rekayasa Geoteknis)”, Jilid I, Erlangga, Jakarta.

Ingles, O.G. and Metcalf, J.B., (1972), Soil Stabilization Principles and Practice, Butterworths, Sidney.

Jingga, Rama, (2008), Stabilisasi Tanah Lempung Dengan Penambahan Pasir dan Semen, Tugas Akhir, Jurusan Teknik Sipil, Fakultas Teknik, Universitas Andalas.

\section{UCAPAN TERIMAKASIH}

Penelitian ini merupakan bagian dari tugas akhir yang dikerjakan oleh mahasiswa bimbingan penulis yang berbakat bernama INDAH SUCIHATI FAEBBA. Untuk itu penulis memberikan apresiasiasi yang sangat besar kepada yang bersangkutan beserta dengan pembimbing lainnya, yaitu bapak Ir. Hendri Gusti Putra, MT.

\section{6 | J URNAL REKAYASA SIPIL}

